JELTL (Journal of English Language Teaching and Linguistics)

e-ISSN: 2502-6062, p-ISSN: 2503-1848

2020, Vol. 5(3)

www.jeltl.org

\title{
Utilizing Digital Comics in College Students' Grammar Class
}

\author{
Dias Tiara Putri Utomo \\ Universitas Muhammadiyah Lamongan \\ diastiara@umla.ac.id \\ Finaty Ahsanah \\ Universitas Muhammadiyah Lamongan \\ finatyahsanah@umla.ac..id
}

\begin{abstract}
The utilization of digital comics in this pandemic situation may become a valuable solution. In fact, many challenges and obstacles faced by students regarding the implementation of online learning. This research aimed at investigating the utilization of digital comics in college students' online grammar class as well as students' responses. The research design was practical action research which followed Mills' model (Creswell, 2012). The participants were 36 nursing college students of a university in Lamongan. The instruments used were observation notes, questionnaire, and student-made comics (artifacts). Then, the data from observation notes and student-made comics were analyzed by Miles, Huberman, \& Saldana's (2014) framework for qualitative data analysis while the data from questionnaire were analyzed by using coding to draw conclusion. The results of the study indicated that (1) there are 4 (four) major steps in utilizing digital comics in grammar learning and (2) students showed positive responses to the utilization of digital comics in learning English grammar indicated by the results of questionnaire. It is expected that educators can take advantage of digital applications such as digital comic makers to deal with online classroom.
\end{abstract}

Keywords: comics, digital comics, learning grammar 


\section{Dias Tiara Putri Utomo \& Finaty Ahsanah}

\section{INTRODUCTION}

In the Covid-19 pademic situation, online teaching can be a challenge as well as burdensome for both educators and students at the same time. Some studies revealed that one of the problems which hindered successful online learning was limited mastery of technology (Ali, 2020; Mastura \& Santaria, 2020) while the others exposed that the problem might in relation with the lack of socialization between students and other students or students and educators (Adnan \& Anwar, 2020; Radha et al., 2020). In other words, students have found it hard to deal with 'unreal' classroom which does not allow them to debate, deliberate or discuss with their teachers or fellows. Eventually, those problems lead to psychological impacts such as frustration, fear, anxiety, apprehension, stress, and even depression (Dhull, 2017)

Such problems were also experienced by nursing students in a university in Lamongan, East Java. They were not familiar with online learning especially in grammar class. Grammar class is the first course they must take before having TOEFL Preparation class in the following semester. To deal with the situation, the researchers conducted a practical action research in order to solve the problem and improve the classroom quality as well. According to Creswell (2012) action research opens opportunity for teachers an educators to improve their teaching practices by taking an action and carrying out research.

The researchers utilized digital comics as a teaching strategy due to their effectiveness for both theoretically and practically. In 2013 Dale Jacobs presented a book entitled Graphic Encounter: Comics and the Sponsorship of Multimodal Literacy to highlight the concept of comics as multimodal text as well as multimodal literacy. Jacobs (2013) defines comics as media which combine texts (words) and visuals (images) in constructing particular meaning. Comics provide readers with complex environment in meaning making process such as, multiple panels, gutters to divide the page, spaces either physical or conceptual, images of objects or people, and word balloons. By recognizing the relationships between comics and multimodal literacy, then educators at any level of education may assisst their students to make meaning through critical ways.

As pointed by Miller (2012) there are five possible reasons to work with graphic novels and comics including differentiation instruction, building critical reading skills, assessing student learning, studying genre, and examining literary elements. Additionally, the use of comics in the classroom may present different pruposes like looking at the different cultures or implementing technology in authentic ways. Indeed, comics are known as remarkable authentic teaching source to cater different types of language aspects. In the light of multiple intelligences, comics suit to not only linguistic intelligence, but also visual intelligence. Furthermore, in Yuliariatiningsih's (2010) study comics developed students' multiple intelligences in the type of verbal-linguistic intelligence, logical-mathematical intelligence, visual-spatial intelligence, interpersonal intelligence, and naturalist intelligence.

Nowadays, comics are also available in the form of digital or electronic. In general, digital comics share the same concept with printed comics such as in terms of visible frames or word balloons; however, they must only be published digitally to be called as digital comics (Aggleton, 2019). Some popular, user-friendly digital comics creators are Canva, Pixton, Story Board That, and Make Belief Comix. These programs let the creator drag and 
drop characters, backgrounds, and speech bubbles onto a digital canvas. They are web based programs and can work in computer or mobile device. Therefore, not having excellent ability in drawing comics will not be a problem because educators can make use of the programs.

In fact, it is not a brand new that digital comics are acknowledged in many educational studies. Wulandari et al. (2019) study explored the use of Webtoon in increasing learners' vocabulary mastery. They considered Webtoon as a student-learning media which provided many features to pursue the students' goal, increased motivation, and were applicable at any situation. On the other hand, Fatimah et al. (2019) found out that ToonDoo was an advantageous application to help teachers provide authentic platform and alluring media in teaching short story. In addition, the use of ToonDoo had enhanced teacher's professional development, which perceived through teacher's creativity in producing digital comics. As one form of digital comic, Widayanti \& Muntaha (2018) investigated the effect of Web Comics in teaching reading comprehension. The study indicated that Web Comics gave positive effect so that it could be used as visual aid in teaching reading and improved students' acheivement. Regarding benefits offered, educators can take into account the use of digital comics in online teaching during Covid-19 pandemic situation.

In summary, the researchers intended to investigate the utilization of digital comics in teaching grammar to college students. In specific, this research was carried out to: (1) investigate the utilization of digital comics in teaching grammar to college students and (2) know college students' responses to the utilization of digital comics in teaching grammar.

\section{LITERATURE REVIEW}

\subsection{Digital Comics}

As mentioned by Jacobs (2013), comics are frequently perceived as the simplified version of word-based text, with pictures to ease the readers in understanding the text. To costruct certain meaning, comics combine what is written with what is drawn, or as multimodal texts, while the activity of reading comics is considered as multimodal literacy, rather than print literacy.

On the other hand, Derrick (2008) states that comic books are called as "visual literacy", in which to decode meanings students must orient themselves toward certain symbols, like what they experience in reading texts. To become a visual literacy, comics show two main elements including visual symbols and shorthand such as, the different use of lines, text bubbles, and dashed or dotted outline. Since different countries might have different visual codes, it is an educator's job to introduce students with those symbols especially in averting confusion. Educators need to help students to be more aware and critical in the ways they construct meaning from comics and other multimodal texts arround them (Jacobs, 2013)

In line with the development of internet, the term "digital comics" has also emerged. In her paper, Aggleton (2019) reveals some cardinal rules regarding digital comics which include their characteristics and aspects. There are three prominent characteristics which cover digital comics. First, they must be published in digital format only or as digital-born comics which meant to be digitally published texts. Second, they must contain a single-panel image or consists of a series of interdependent images. Third, they must have a semi-guided reading pathway because they consist of writing (guided reading pathway) and images 


\section{Dias Tiara Putri Utomo \& Finaty Ahsanah}

(unguided reading pathway), in which comics lie between those two. In terms of aspects, comics must contain visible frames, iconic symbols, and handwriting style. On the other hand, they must not be merely a moving image/picture or an audio.

Silva et al. (2017) explored the use of comics as a teaching strategy. There are five main phases including recognition phase, planning phase, action phase, observation and reflection phase. In the recognition phase, teacher introduces the strategy to creat comics and goal of the activity. In planning phase, students are asked to have individual activity reflection. Action phase consists of two activities, namely forming small group and developing comics in group. Observing and reflecting comics are carried out trough presenting comics in class and encouraging reflection. Those phases were adapted by the researchers in order to suit students' needs and situation.

Eventually, Lavery (2011) presents three suggested activities in implementing cartoons and comics strips, namely activities for exploiting cartoons/comic strips, activities for using comics strips, and exploiting characters.

\subsection{Grammar}

There are some definitions of grammar expressed by different educational experts. Richards \& Schmidt (2010) defines grammar as a description of language structure and how linguistic units such as words or phrases are combined to make sentence. In his book entitled The Study of Language, Yule (2010) perceives grammar as the process of describing phrases or sentences structure in a certain way to figure out whether they are grammatical sequences or ungrammatical sequences. Another definition is presented by Huddleston \& Pullum (2005) who state that a language grammar describes the main rule for setting form and meaning of words, phrases, clauses, and sentences. Furthermore, they also mentions two components of grammar, namely syntax and morphology. Syntax deals with how the words are combined to form phrases, clauses, and sentences, while morphology is related to the word formation process. In short, grammar can be defined as rules dealing with language structures and the way to arrange them to be meaningful.

Regarding its definition, it has been clear that to be successful language users, learners must master grammar since it will enable them to consturct better language sturcture and make maningful massage. Students have figured out that grammar knowledge is essential for improving their language skills, however, they also realize that learning grammar can be an arduous job. Navaz \& Sama (2017) reported that memorizing grammar rules and studying grammar examples were two ways of learning grammar by university students in Sri Lanka. Furthermore, they also suggested that learning grammar had to be performed in integrated teaching with other skills. The students felt boring when grammar learning was carried out explicitly. In addition, Mahdi (2018) reported that the largest percentage of grammar errors in writing made by university students in Iraq was in the corerct use of 'verb'. The reasons were due to traditional teaching method and students' lack of motivation. In fact, monotonous grammar class affect students' low motivation. In many cases, teachers do not provide any teaching media, but keep using grammar textbook instead.

Thus, determining proper method in teaching grammar will be fruitful for both educators and students. Educators can make use of diverse media in teaching grammar. Al 
Faruq \& Nurhalimah (2018) utilized comic strips as media for teaching simple past tense and found out that the media resulted in significant improvement toward students' score. On the other hand, Cabrera et al. (2018) had also exploited Pixton as one of comic creator websites to teach grammar and vocabulary. The results indicated that Pixton was an effective medium to enhance EFL students' competence in grammar and vocabulary.

\section{RESEARCH METHODS}

This was an action research especially practical action research. This design was applied because the researchers intended to improve students' learning and increase researchers' own professional development, as well as to bridge the gap between theory and practice. The researchers followed Mills' Dialectic Action Research Spiral model in Creswell (2012) consisting of four prominent steps: identifying an area of focus, collecting data, analyzing and interpreting data, and developing an action plan.

The participants of this study were 36 students of second semester nursing study program especially transfer class. They were diverse in age and background. Most of them had been working in hospital while the rest had not yet working. In their second semester, they had to enroll grammar class before taking TOEFL preparation class in the third semester. They were selected to be the participants of the study because they had to go through grammar class by online classroom. This study was performed for seven (7) meetings of online classroom, through the assistance of video communication platform Zoom. The outbreak of Covid-19 Pandemic in March 2020 had shifted face-to-face meeting to distance learning through online meeting. Throughout the year online learning had been an issue because many students did not familiar with this method.

According to Mills in Creswell (2012), there are three data collection techniques in action research, namely experiencing, enquiring, and examining. In this research, experiencing was in the form of passive observation, enquiring was held through distributing questionnaire to obtain students' responses, and examining was carried out through collecting students' artifacts. Thus, the instruments used were observation sheet, questionnaire, and artifacts. The observation sheet was utilized to register different aspects related to teaching activities and strategies as well as students attitudes in the class. The questionnaire was distributed to students with the purpose of determining students' responses toward the utilization of digital comics in grammar learning. It was consisted of 8 close-ended questions and adapted from Cabrera et al. (2018) research which focused on the impact of using Pixton for teaching grammar. Eventually, the artifacts were in the form of students-made comics which summarizing a grammar topic in each meeting.

The analysis was carried out in accordance with the available data. Data of observation notes and students' artifacts were analyzed using Miles et al. (2014) framework for qualitative data analysis including data reduction, data condensation, and data display. The questionnaires were analyzed by using coding to draw conclusion.

\section{FINDINGS AND DISCUSSIONS}

The findings present two considerable points: the utilization of digital comics in grammar class and students' responses to the utilization of digital comics. 


\section{Dias Tiara Putri Utomo \& Finaty Ahsanah}

\subsection{The Utilization of Digital Comics in Grammar Class}

There are diverse ways in which comics may immerse to language classroom. This research followed Lavery's (2011) suggestion on activities for using comics in the classroom consisting of three activities: exploiting comics, using comics, and exploiting characters. In exploiting comics, students have opportunities to explore the theme of humor and dealing with certain issues. In terms of using comics, students may tell the story or construct new comic strips. In exploiting characters, students will create their own comic strips characters, discuss the characters, and make use of short sequences for sketches and improvisation.

However, few modifications have been made in order to suit students' needs as well as learning objective. First, lecturer took several time to present digital comics with the aiming of providing general depiction toward the topic including the characters, setting, and grammar material. The learning process was performed through online video communication platform Zoom. The lecturer presented digital comics through the feature of share screen. By this way, students could see the leacturer's digital comics while listening to the explanation.

Second, the lecturer started to exploit digital comics by exploring the theme of humour. The lecturer prompted some questions to ease students understand the humour showed in the comics. The students answered the lecturer's questions and stated their random ideas. At first, students did not recognize the humour in the comics due to the difference in culture. However, as the time went by the students could understand. Humour is useful for initating and developing students' knowledge about English-speakers' culture and sense of humour (Derrick, 2008). The presence of humor has created a possitive learning atmosphere because it makes students feel relaxed and comfortable. Humour uses word play which can stimulate human to smile and laugh for those who see it (Wijana, 2004).

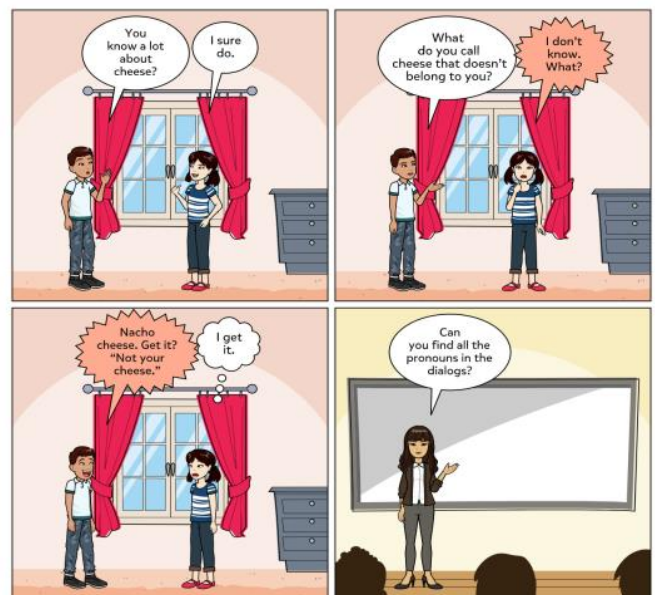

Figure 1. Digital Comics which discuss 'pronoun'

Third, students were asked to focus on the target grammar by retelling digital comics' story and highlighting the important points in the topic. Digital comics contain a set of interdependent images which open opportunity for students to freely retell the story by their own sentences. For this purpose, the students needed to turn on their audio and video 
features so that lecturer and other students could hear and see the explanation. The use of digital comics had been proven effective in improving students' ability in retelling story (Fatimah et al., 2019) . The assistance of digital comics may reduce students' axiety in speaking. Moreover, after retelling the story, students learned target grammar thorugh the contexts from the text inside words balloons and answered some questions. The grammar questions were still in relation to the comics. Then, the lecturer and students reflected their teaching practice by discussing and summarizing the material.

Fourth, students were asked to make digital comics together with their group. The groups were determined at the first meeting consisting of 4 students each group. Studentsmade comics contained the summary of grammar learning and had to be completed outside the classroom hour. This last step was adapted from Silva et al. (2017) strategy. However, in this step the students did not need to present their comics in the classroom. The students had to submit their digital comics to the lecturer via e-mail. The lecturer collected students-made comics to be evaluated and analyzed.

In short, these are four steps in utilizing digital comics in online grammar teaching:

1) Presenting digital comics to provide general depiction of the topic

2) Exploring the theme of humour to build a possitive learning atmosphere

3) Focusing on the target grammar

4) Making digital comics in group

\subsection{Students' Responses to the Utilization of Digital Comics in Grammar Class}

The data on students' responses were obtained through questionnaire distributed to the students. There were 8 questions adapted from Cabrera et al. (2018). The results showed that $80 \%$ of the students felt the use of digital comics was effective in learning grammar, where exactly $53,5 \%$ was very effective and $26,7 \%$ was highly effective as perceived in Chart 1 .

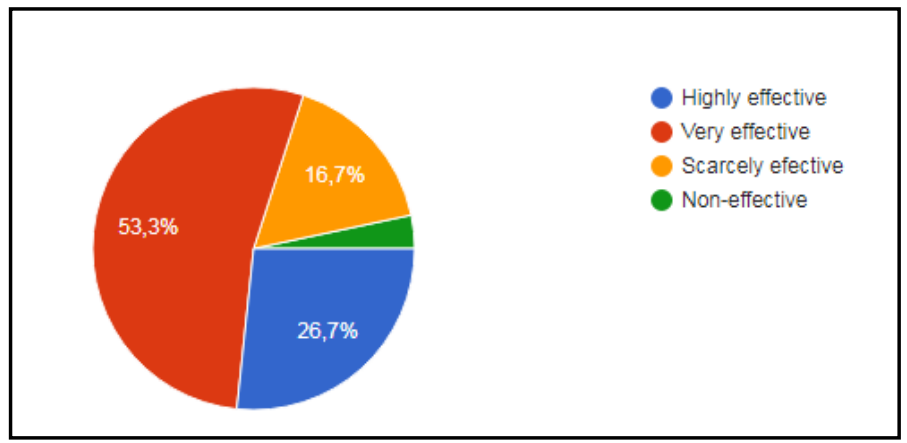

Chart 1. Students' Perceptions of the Effectiveness of Digital Comics in Learning Grammar

The results are in accordance with the research findings by Cabrera et al. (2018) and Al Faruq \& Nurhalimah (2018). In Cabrera et al. (2018), digital comics from Pixton had proven to be an effective tool to teach as well as enhance EFL grammar because students in the experimental group showed significant increase in their score. While in Al Faruq \& Nurhalimah (2018) research, students in experimental group, who were taught grammar simple past tense using comic strips, achieved better in their average score than the control 


\section{Dias Tiara Putri Utomo \& Finaty Ahsanah}

group. This means that comic strips were effective for teaching grammar especially simple past tense.

The second question elaborated why students liked digital comics in learning English grammar. The results indicated that $56.3 \%$ of the students assumed learning grammar through the use of digital comics was not boring while $21.9 \%$ of them felt that digital comics enhanced their creativity. The complete results can be perceived in Chart 2.

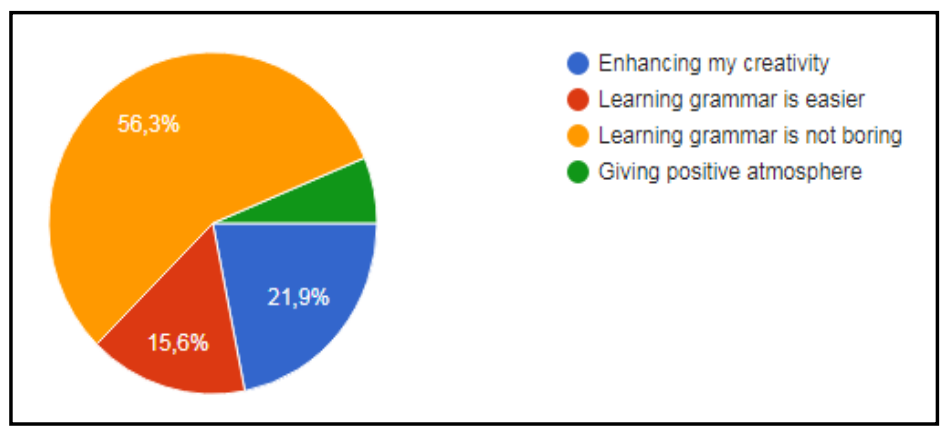

Chart 2. Students' Positive Perceptions of the Utilization of Digital Comics in Learning Grammar

As it is stated by Navaz \& Sama (2017), learning grammar explicitly or without being integrated with other skills resulted in boring learning. Therefore, the presence of appealing media like digital comics can turn boring classroom to the interesting one. From classroom observations, it indicated that students showed active participation during the lesson particularly when the lecturer asked theme of humour and discussed grammar worksheet. Furthermore, the students enthusiatically answered lecturer's questions either via written in chat box or spoken directly.

According to Al Faruq \& Nurhalimah (2018), a lot of pictures made classroom with digital comics interesting. The existance of pictures/images in the digital comics bring a fascinating insight into the students. Pictures also aid students to make meaning, manage information, recognize the relation of ideas, and visualize them into mental models (Widayanti \& Muntaha, 2018). Additionally, it has been proven that pictures in digital comics had increased students' creativity, which affected to their ability in solving problems (Putra \& Iqbal, 2014). Students' creativity considered increase when they were working on their comics projects. As perceived in students-made comics, in each meeting they presented different characters, scenery, and story.

Furthermore, the third question has revaled that the students felt interested $(50 \%)$, motivated $(34.4 \%)$, and actively engaged (9.4\%) in the learning process as perceived in Chart 3. This result is in accordance with Badriah's (2017) investigation toward the use of comics to allow students' creativity. Retelling comics presented students with fun, interesting, and motivating learning atmosphere. Retelling comics is the third step of utilizing digital comics in this research. 


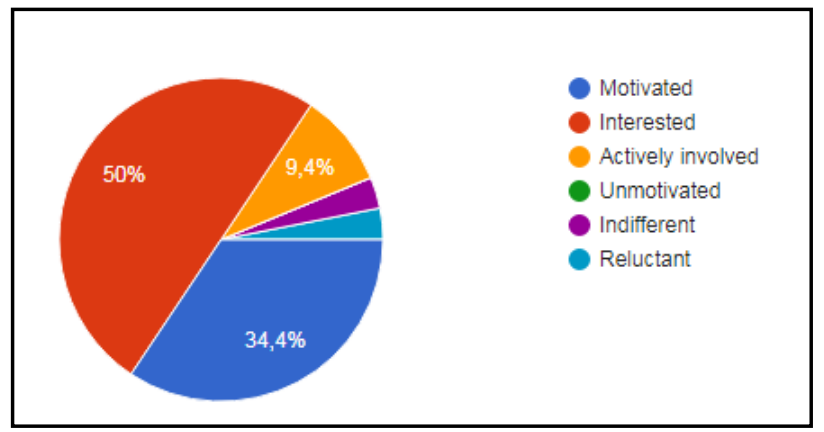

Chart 3. Students' Reactions to Digital Comics in Learning Grammar

In terms of lecturer's instruction, the students considered lecturer's intructions when teaching grammar using digital comics were very effective $(62.5 \%)$, highly effective $(28.1 \%)$, and scarcely effective $(9.4 \%)$, and none of the students considered the instructions non-effective. Digital comics made clear direction toward the learning process and helped students focus on the instruction (Putra \& Iqbal, 2014). In addition, 96\% of the students decided language of the dialogs was clear and appropriate and $96.9 \%$ of them also stated that the images/pictures in the digital comics were clear and appropriate. All of them agreed that the characters and scenery were attractive $(100 \%)$. Thus, $93.8 \%$ of them wanted the lecturer use digital comics in their next class. To sum up, the students have demonstrated positive response to the utilization of digital comics in grammar class as perceived in the results of questionnaire.

\section{CONCLUSIONS}

The research resulted in the conclusions drawn as follows. First, there are four major steps in utilizing digital comics. First, lecturer presents digital comics to provide general depiction of the topic. Second, students explore the theme of humour to build a possitive learning atmosphere. Third, students focus on the target grammar. Fourth, students make digital comics in group as their project.

Second, the students showed positive responses to the utilization of digital comics in learning English grammar. The statement is supported by the results of questionnaire. Eventually, the researcher suggests educators take part in developing digital comics used for teaching other English skills and components. Furthermore, educators can take advantage of other digital applications or websites that are beneficial in improving online learning quality.

\section{REFERENCES}

Adnan, M., \& Anwar, K. (2020). Online Learning Amid The Covid-19 Pandemic: Students Perspectives. Journal Of Pedagogical Research, 2(1), 45-51. https://doi.org/10.33902/Jpsp.2020261309

Aggleton, J. (2019). Defining Digital Comics: A British Library Perspective. Journal Of Graphic Novels And Comics, 10(4), 393-409. https://doi.org/10.1080/21504857.2018.1503189 
Al Faruq, H. A., \& Nurhalimah, N. (2018). Comic Strips In Teaching Simple Past Tense For Efl Learners. Ellite: Journal Of English Language, Literature, And Teaching, 3(2), 53. dttps://doi.org/10.32528/Ellite.V3i2.1912

Ali, W. (2020). Online And Remote Learning In Higher Education Institutes: A Necessity In Light Of Covid-19 Pandemic. Higher Education Studies, 10(3), 16. https://doi.org/10.5539/Hes.V10n3p16

Cabrera, P., Castillo, L., González, P., Quiñónez, A., \& Ochoa, C. (2018). The Impact Of Using Pixton For Teaching Grammar And Vocabulary In The EFL Ecuadorian Context. Teaching English With Technology, 18(1), 53-76.

Creswell, J. W. (2012). Educational Research: Planning, Conducting, And Evaluating Quantitative And Qualitative Research (4th Ed). Pearson.

Derrick, J. (2008). Using Comics With ESL/EFL Students. The Internet Tesl Journal, $X I V(7), 6$.

Dhull, I. (2017). Online Learning. International Education \& Research Journal, 3(8), 32-34.

Fatimah, A. S., Santiana, S., \& Saputra, Y. (2019). Digital Comic: An Innovation Of Using Toondoo As Media Technology For Teaching English Short Story. English Review: Journal Of English Education, 7(2), 101-108. https://doi.org/10.25134/Erjee.V7i2.1526

Huddleston, R., \& Pullum, G. (2005). A Student's Introduction To English Grammar. Cambrigde University Press.

Jacobs, D. (2013). Graphic Encounter: Comics And The Sponsorship Of Multimodal Literacy. Bloomsbury Academic.

Lavery, C. (2011). Using Cartoons And Comic Strips. Teachingenglish.Org.Uk. Https://www.Teachingenglish.org.Uk/Article/Using-Cartoons-Comic-Strips

Mahdi, A. (2018). Difficulties In Learning Grammar, A Study Into The Context Of University Of Technology, Department Of Materials Engineering. Lark Journal For Philosophy, Linguistics, And Social Sciences, 1(31), 23-31.

Mastura, \& Santaria, R. (2020). Dampak Pandemi Covid-19 Terhadap Proses Pengajaran Bagi Guru Dan Siswa. Jurnal Studi Guru Dan Pembelajaran, 3(2), 289-295. https:doi.org/10.30605/Jsgp.3.2.2020.293

Miles, M., Huberman, A., \& Saldana, J. (2014). Qualitative Data Analysis: A Method Sourcebook. Sage Publications.

Miller, A. (2012, January 11). Using Graphic Novels And Comics In The Classroom. Edutopia.Org. https://www.Edutopia.Org/Blog/Graphic-Novels-Comics-Andrew-Miller

Navaz, A., \& Sama, F. (2017). Teaching Grammar In The English Language Classroom: Perceptions And Practices Of Students And Teachers In The Ampara District. Proceedings Of 7th International Symposium, 16. http://Ir.Lib.Seu.Ac.Lk/Handle/123456789/3051

Putra, P., \& Iqbal, M. (2014). Implementation Of Digital Comic To Improve Creative Thinking Ability In Integrated Science Study. 71-74. https://doi.Org/10.13140/Rg.2.1.4299.7286

Radha, R., Mahalakshmi, K., Kumar, D. V. S., \& Saravanakumar, D. A. (2020). E-Learning During Lockdown Of Covid-19 Pandemic: A Global Perspective. International Journal Of Control And Automation, 13(4), 1088-1099. 
Richards, J., \& Schmidt, R. (2010). Longman Dictionary Of Language Teaching And Applied Linguistics (Fourth). Pearson Education Limited.

Silva, A. B. D., Santos, G. T. D., \& Bispo, A. C. K. D. A. (2017). The Comics As Teaching Strategy In Learning Of Students In An Undergraduate Management Program. Ram. Revista De Administração Mackenzie, 18(1), 40-65. https://doi.org/10.1590/167869712017/Administracao.V18n1p40-65

Widayanti, A., \& Muntaha, M. (2018). Islamic Web Comics As Visual Aid In Teaching English For Islamic Secondary School Students. Indonesian Journal Of Islamic Literature And Muslim Society, 3(1), 75-90. https://doi.org/10.22515/Islimus.V3i1.1298

Wijana, I. (2004). Kartun: Studi Tentang Permainan Bahasa. Ombak.

Wulandari, R. A., Lestari, R. E., \& Utami, L. (2019). The Effectivness Of Webtoon For Efl Student In Mastering Vocabulary. 10.

Yule, G. (2010). The Study Of Language (Fouth). Cambrigde University Press.

Yuliariatiningsih, M. S. (2010). Media Komik Pada Pelajaran Ipa Untuk Meningkatkan Multiple Intelligences Siswa Sd. Eduhumaniora | Jurnal Pendidikan Dasar Kampus Cibiru, 2(2). https://doi.org/10.17509/Eh.V2i2.2769 